\title{
Can Ki-67 Predict Pelvic Node Status in Endometrial Adenocarcinoma?
}

\begin{abstract}
Background: The $\mathrm{Ki}-67$ marker is a nuclear protein that has a direct correlation with the degree of cells proliferation that often expressed
\end{abstract} in human neoplasm.

Objective: To evaluate utilization of $\mathrm{Ki}-67$ expression as predicto for pathological nodal positivity in endometrial endometrioid adenocarcinoma.

Design: A retrospective case control study.

Settings: Tertiary cancer center.

Materials and methods: We evaluated 12 histopathologic al slides for patients with endometrioid adenocarcinoma of the uterus for percentage of expression of $\mathrm{Ki}-67$. We defined high expression as $\mathrm{Ki}-67$ stained $>50 \%$ of tumor cells.

Main outcome measures: The correlation of Ki-67 high expression rates and pelvic node positivity in endometrioid adenocarcinoma.

Results: Our sample mean age at diagnosis is (58.25 years) and median age is ( 57 years). The rate of high expression of Ki-67 in tumor cells among cases with positive lymph nodes vs controls were significantly higher $(83 \%)$ vs $(17 \%)$, with ( $p$-value $=0.04)$. There were no significant differences between the mean age in cases and controls (59.8 vs 56.67) with $(p=0.67)$, tumor grade $(p=0.3)$, myometrium invasion $(p=0.1)$, cervical stromal invasion $(p=0.2)$, lymphovascular invasion $(p=0.2)$. On multivariate analysis a high expression of $\mathrm{Ki}-67$ continued to be independent predictor for lymph node positivity ( $\mathrm{p}$ $=0.02)$.

Conclusions: This finding suggests that a high expression of $\mathrm{Ki}$ 67 plays an important role as predictor for lymph node positive in endometrioid adenocarcinoma. The level of expression of Ki-67 can be utilized for preoperative or postoperative risk assessment to predict for lymph node metastasis for cases with borderline indications for postoperative pelvic iradiation. Further prospective larger study is needed to validate this preliminary data.

\section{Background}

Endometrial cancer (EC) is the most common malignancy of the female genital tracts and the fourth most common cancer occurring in women after breast, bowel and lung cancers [1]. Total abdominal hysterectomy and bilateral salpingo oophorectomy (TAHBSO) is the standard surgical intervention for early endometrial adenocarcinoma. Addition of pelvic lymph node dissection remains controversial issue, several meta analyses and database analysis showed no differences in overall or recurrence free survival between females who had lymphadenectomy and those who did not undergo for lymphadenectomy with higher surgical morbidities in lymphadenectomy patients [2-4]. Although in early stage endometrial cancer patients the risk for lymph node metastasis is low, still adjuvant pelvic radiation is widely recommended following TAHBSO aiming to reduce pelvic recurrence. The Gynecology Oncology Group -33 study (GOG 33) identified several pathological risk factors significantly predict for lymphatic metastasis which are

\section{Journal of}

\section{Cancer Sciences}

Tahani H Nageeti ${ }^{1 *}$, Raid A Jastania ${ }^{2}$, Mervet $Y$ Omer $^{1}$, Arwa Al-Zahrani², Amal Al-Turkistani², Bushra Al-Ahmadi², Maha Al-Dahwani ${ }^{2}$ and Waad Al-Otaibi

${ }^{1}$ Jeddah Oncology Centre, King Abdullah Medical City-Holly Capital, Jeddah, Saudi Arabia

${ }^{2}$ Umm Al-Qura University, Mecca, Saudi Arabia

*Address for Correspondence

Tahani H Nageeti, MB, ChB, FRCPC, Consultant Radiation Oncology, Jeddah Oncology Centre, King Abdullah Medical City-Holly Capital, Jeddah, Saudi Arabia, E-mail: nageeti@hotmail.com

Submission: 16 September, 2016

Accepted: 23 November, 2016

Published: 28 November, 2016

Copyright: ๑ 2016 Nageeti TH, et al. This is an open access article distributed under the Creative Commons Attribution License, which permits unrestricted use, distribution, and reproduction in any medium, provided the original work is properly cited.

currently used in different algorithm to recommend adjuvant therapy which are: tumor grade, depth of myometrial invasion, and vascular space invasion [5].

Immunohistochemical (IHC) method has been very useful for detecting several markers of possible prognostic importance for a number of cancer types. The Ki-67 protein is an (IHC) marker of cell proliferation associated nuclear antigen which is expressed in dividing cells during cell cycle (G1, S, G2 and M) but not on (G0) $[6,7]$. The labeling index of Ki-67 has a direct correlation with the degree of cells proliferation, and has prognostic value in several types of cancer [8-12]. The Ki-67 is a commonly used proliferation marker in breast cancer. Some data showed a high Ki-67 was significantly associated with a short disease free interval [13]. Recently, a high Ki-67 expression is being utilized as IHC marker to predict for a better response to systemic therapy in subgroup of patient with luminal-B ductal carcinoma of breast and borderline indication for chemotherapy $[14,15]$.

Several publications on utilization of IHC markers and other biomarkers in endometrial disorders found that expression of $\mathrm{Ki}$ 67 may play an important role in identifying endometrial cancer transformation and cell differentiation [16-21]. Other found that high levels of proliferation and expression of Ki-67 with other biomarkers were predictive of recurrence in low grade Endometrial Stromal Sarcomas [22].

Since Ki-67 is a nuclear protein that has a direct correlation with the degree of cell proliferation, we hypothesized that Ki-67 marker be highly expressed in pathologically nodal positive endometrial adenocarcinoma.

\section{Study Objective}

To evaluate if high expression of $\mathrm{Ki}-67$ in endometrial endometrioid adenocarcinoma can predict pathological lymph nodes positivity.

\section{Patients and Methods}

We conducted a retrospective case control study on adult patients' samples who presented with histologically confirmed endometrioid 
Citation: Nageeti TH, Jastania RA, Omer MY, Al-Zahrani A, Al-Turkistani A, et al. Can Ki-67 Predict Pelvic Node Status in Endometrial Adenocarcinoma? J Cancer Sci. 2016;3(1): 1.

ISSN: 2377-9292

Table 1: Study population characteristics.

\begin{tabular}{|c|c|c|c|c|c|c|c|c|c|c|}
\hline Lymph Node & Age & Histopathology Type & $\begin{array}{l}\text { Tumor } \\
\text { Grade }\end{array}$ & $\begin{array}{l}\text { Cervical } \\
\text { stromal } \\
\text { Involve- } \\
\text { ment }\end{array}$ & $\begin{array}{l}\text { Myometrial Inva- } \\
\text { sion }\end{array}$ & LVI & $\begin{array}{l}\text { Ki-67 Expres- } \\
\text { sion }\end{array}$ & $\begin{array}{l}\text { Sur- } \\
\text { gery }\end{array}$ & $\begin{array}{l}\text { Radiation } \\
\text { after } \\
\text { surgery }\end{array}$ & CTH \\
\hline $\begin{array}{l}\text { Negative } \\
\text { (controls) }\end{array}$ & $\begin{array}{c}\text { Mean }=56.67 \\
\text { Median }=53.5 \\
\text { SD }=12\end{array}$ & & & & & & & & & \\
\hline 1 & 47 & Endometrioid Adenocarcinoma & Grade III & absent & $<50 \%$ & Positive & $\leq 50 \%$ & Yes & Yes & No \\
\hline 2 & 51 & Endometrioid Adenocarcinoma & Grade I-II & absent & $<50 \%$ & $\begin{array}{l}\text { Nega- } \\
\text { tive }\end{array}$ & $\leq 50 \%$ & Yes & No & No \\
\hline 3 & 46 & Endometrioid Adenocarcinoma & Grade I-II & absent & $<50 \%$ & $\begin{array}{l}\text { Nega- } \\
\text { tive }\end{array}$ & $\leq 50 \%$ & Yes & Yes & No \\
\hline 4 & 56 & Endometrioid Adenocarcinoma & Grade I-II & absent & $<50 \%$ & $\begin{array}{l}\text { Nega- } \\
\text { tive }\end{array}$ & $\leq 50 \%$ & Yes & Yes & No \\
\hline 5 & 62 & Endometrioid Adenocarcinoma & Grade I-II & present & $<50 \%$ & Positive & $\leq 50 \%$ & Yes & Yes & No \\
\hline 6 & 78 & Endometrioid Adenocarcinoma & Grade I-II & present & $>50 \%$ & $\begin{array}{l}\text { Nega- } \\
\text { tive }\end{array}$ & $>50 \%$ & Yes & Yes & No \\
\hline $\begin{array}{l}\text { Positive } \\
\text { (Cases) }\end{array}$ & $\begin{array}{c}\text { Mean }=59.8 \\
\text { Median }=63.5 \\
\text { SD }=13.5\end{array}$ & & & & & & & & & \\
\hline 1 & 69 & Endometrioid Adenocarcinoma & Grade I-II & present & $<50 \%$ & $\begin{array}{l}\text { Nega- } \\
\text { tive }\end{array}$ & $>50 \%$ & Yes & Yes & Yes \\
\hline 2 & 70 & Endometrioid Adenocarcinoma & Grade I-II & present & $>50 \%$ & Positive & $\leq 50 \%$ & Yes & Yes & Yes \\
\hline 3 & 47 & Endometrioid Adenocarcinoma & Grade III & present & $>50 \%$ & Positive & $>50 \%$ & Yes & No & Yes \\
\hline 4 & 58 & Endometrioid Adenocarcinoma & Grade I-II & absent & $<50 \%$ & $\begin{array}{l}\text { Nega- } \\
\text { tive }\end{array}$ & $>50 \%$ & Yes & No & Yes \\
\hline 5 & 41 & Endometrioid Adenocarcinoma & Grade I-II & absent & $>50 \%$ & Positive & $>50 \%$ & Yes & Yes & Yes \\
\hline 6 & 74 & Endometrioid Adenocarcinoma & UnSP & UnSP & UnSP & UnSP & $>50 \%$ & No & No & No \\
\hline $\begin{array}{c}\text { Total Population } \\
=12\end{array}$ & $\begin{array}{c}\text { Mean }=58.25 \\
\text { Median=57 } \\
\text { SD }=12.3\end{array}$ & & & & & & & & & \\
\hline
\end{tabular}

SD: Standard Deviation; CTH: Chemotherapy; LVI: Lymphovascular Invasion; UnSP: UnSpecified

adenocarcinoma of the uterus. The study was conducted in tertiary cancer center at King Abdullah Medical City. The protocol was reviewed and approved by institutional review board. Population was identified via search of hospital Electronic Medical Records between June of 2014 and June of 2016. We identified 48 cases with endometrial adenocarcinoma, then we identified 6 cases with pelvic node positive disease with no distance metastasis and we identified 6 matched controls of node negative. We match the cases and control for age and other clinicopathological characteristics including: tumor grade, lymphovascular space invasion, myometrial invasion and cervix invasion. The Immunohistochemical stain of Ki-67 was carried on unstained pathological slides taken from formalin-fixed, paraffinembedded tissues by standard automated immunohistochemistry on Ventana machine.

We defined high expression as Ki-67 staining $>50 \%$ of tumor cells. All readings of the percentage of Ki-67 were carried out by one pathologist to overcome observers' variation (Figures 1 and 2).

\section{Statistical analysis}

Collected data was transferred and analyzed by using SPSS ver. 24 (SPSS Inc.). The correlation of high expression of Ki-67 with pelvic node positive and other factors was tested using the Pearson chisquare test and Fisher exact test. Multivariate model was estimated using the back-ward logistic regression method for statistical significance of a P-value $<0.05$.

\section{Result}

All 12 patients had confirmation of endometrial endometrioid adenocarcinoma; all underwent TAHBO and pelvic lymph node dissection (Table 1). Population mean age at diagnosis is ( 58.25 years) and median age is (57 years). We found the rate of high expression of Ki-67 in cells among cases with positive lymph nodes (83\%) vs controls with negative lymph nodes (17\%), which was significantly higher ( $\mathrm{p}$-value $=0.04)$. There were no significant differences between the mean age in cases and controls $(59.8$ vs 56.67$)$ with $(\mathrm{p}=0.67)$, tumor grade $(\mathrm{p}=0.3)$, myometrial invasion $(\mathrm{p}=0.1)$, cervical stromal invasion $(\mathrm{p}=0.2)$, lymphovascular invasion $(\mathrm{p}=0.2)$. On multivariate analysis a high expression of Ki-67 continued to be independent predictor variable for lymph node positivity $(\mathrm{p}=0.02)$.

\section{Discussion}

Endometrial adenocarcinoma of the uterus is the most common cancer of female genital tracts. Majority of cases present in early stage disease, and assessment of the risk for pelvic node metastasis is the most important prognostic factor that predicts for relapse. Currently in our clinical practice we offer pelvic lymph node dissection and/or pelvic node irradiation to almost all patients with early disease and this mainly because we could not identified patients with higher risk for pelvic nodal metastasis based on histopathological data alone. 


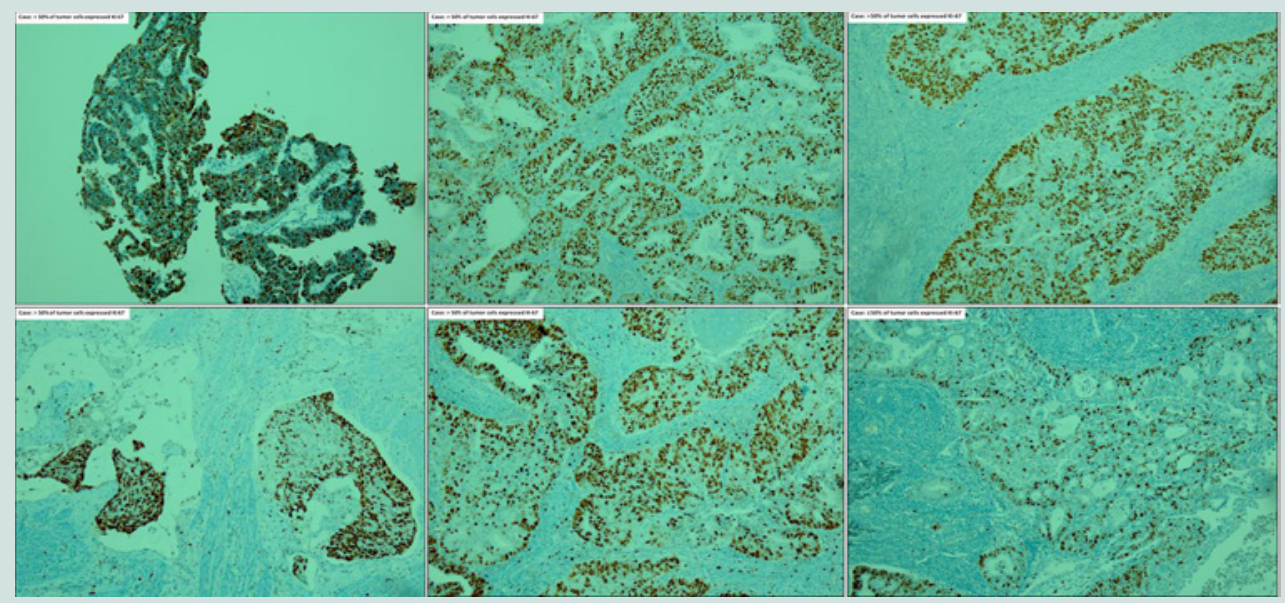

Figure 1: Immunohistochemical stain for Ki-67. In 5 out of 6 cases, there is high percentage of nuclear stains in tumor cells, more than $50 \%$.

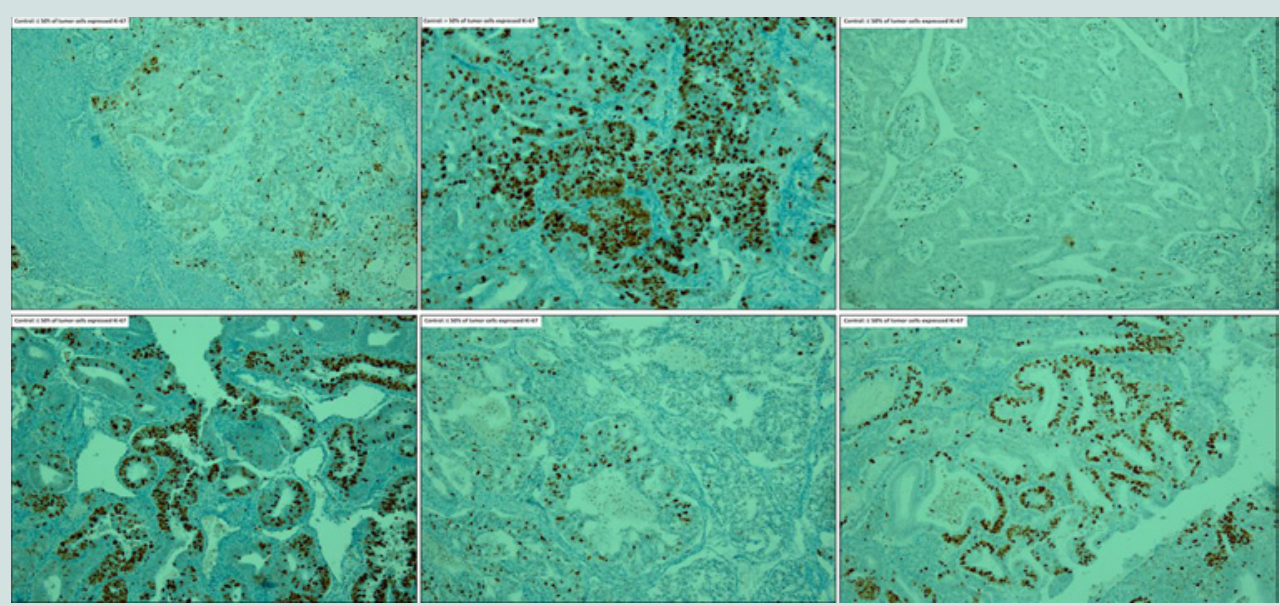

Figure 2: Immunohistochemical stain for Ki-67. In 5 out of 6 controls, there is low percentage of nuclear stains in tumor cells.

Tumor cells proliferation is an important biological parameter that reflects disease behavior, which might also predicts for disease prognosis. The nuclear protein Ki-67 is a proliferative marker and widely used prognostic indicator in several cancer diagnosis, including breast cancer, bladder cancer, gastrointestinal neuroendocrine tumor, oral cancer, lung cancer, astrocytoma, and pituitary adenoma $[8-12,23,24]$.

In endometrial cancers, $\mathrm{Ki}-67$ in addition to other biomarkers was found to be useful marker to distinguish benign proliferative conditions from cancer precursors and low grade endometrioid adenocarcinomas $(16,25)$. In a study on 270 endometrial samples Ki-67 expression was found to be higher in samples with high-grade endometrioid carcinomas vs normal endometrial samples [26].

\section{Conclusion}

Our data suggests that high expression of Ki-67 (> 50\% of tumor cells) is correlated with microscopic pelvic lymph node positive metastasis of endometrioid adenocarcinoma of the uterus. This IHC marker can be utilized as additional predictor to other histopathological prognostic factors to identify group of patients with true high risk pelvic nodal microscopic metastasis, whom are actually benefit from adjuvant pelvic nodal irradiation in early endometrioid adenocarcinoma.

\section{Limitations}

At the end we have to address some of the limitations of our results which are due to the retrospective nature of the study and small sample size. Our team is planning to validate this preliminary data by conducting a prospective analysis on a larger sample size.

\section{References}

1. Siegel RL, Miller KD, Jemal A (2016) Cancer statistics, 2016. CA Cancer J Clin 66: 7-30.

2. Frost JA, Webster KE, Bryant A, Morrison J (2015) Lymphadenectomy for 
Citation: Nageeti TH, Jastania RA, Omer MY, Al-Zahrani A, Al-Turkistani A, et al. Can Ki-67 Predict Pelvic Node Status in Endometrial Adenocarcinoma? J Cancer Sci. 2016;3(1): 1.

the management of endometrial cancer. Cochrane Database Syst Rev 9 : CD007585

3. Wright JD, Huang Y, Burke WM, Tergas Al, Hou JY, et al. (2015) Influence of lymphadenectomy on survival for early-stage endometrial cancer. Obstet Gynecol 127: 109-118

4. May K, Bryant A, Dickinson HO, Kehoe S, Morrison J (2010) Lymphadenectomy for the management of endometrial cancer. Cochrane Database Syst Rev 1: CD007585.

5. Creasman WT, Morrow CP, Bundy BN, Homesley HD, Graham JE, et al. (1987) Surgical pathologic spread patterns of endometrial cancer. A gynecologic oncology group study. Cancer 60: 2035-2041.

6. Gerdes J, Lemke H, Baisch H, Wacker HH, Schwab U, et al. (1984) Cell cycle analysis of a cell proliferation-associated human nuclear antigen defined by the monoclonal antibody Ki-67. J Immunol 133: 1710-1715.

7. Gerdes J, Li L, Schlueter C, Duchrow M, Wohlenberg C, et al. (1991) Immunobiochemical and molecular biologic characterization of the cell proliferation-associated nuclear antigen that is defined by monoclonal antibody Ki-67. Am J Pathol 138: 867-873.

8. Luo Y, Zhang X, Mo M, Tan Z, Huang L, et al. (2016) High Ki-67 immunohistochemical reactivity correlates with poor prognosis in bladder carcinoma: a comprehensive meta-analysis with 13,053 patients involved Medicine (Baltimore) 95: e3337.

9. Tabata K, Tanaka T, Hayashi T, Hori T, Nunomura S, et al. (2014) Ki-67 is a strong prognostic marker of non-small cell lung cancer when tissue heterogeneity is considered. BMC Clin Pathol 14: 23.

10. Jamali M, Chetty R (2008) Predicting prognosis in gastroentero-pancreatic neuroendocrine tumors: an overview and the value of Ki-67 immunostaining Endocr Pathol 19: 282-288.

11. Yu YH, Morales J, Feng L, Lee JJ, El-Naggar AK, et al. (2015) CD147 and $\mathrm{Ki}-67$ overexpression confers poor prognosis in squamous cell carcinoma of oral tongue: a tissue microarray study. Oral Surg Oral Med Oral Pathol Ora Radiol 119: 553-565.

12. Kurebayashi J, Kanomata N, Shimo T, Yamashita T, Aogi K, et al. (2014) Marked lymphovascular invasion, progesterone receptor negativity, and high Ki67 labeling index predict poor outcome in breast cancer patients treated with endocrine therapy alone. Breast Cancer 21: 214-222.

13. Ohara M, Matsuura K, Akimoto E, Noma M, Doi M, et al. (2016) Prognostic value of Ki67 and p53 in patients with estrogen receptor-positive and human epidermal growth factor receptor 2-negative breast cancer: Validation of the cut-off value of the Ki67 labeling index as a predictive factor. Mol Clin Oncol 4: 648-654.

14. Li H, Han X, Liu Y, Liu G, Dong G (2015) Ki67 as a predictor of poor prognosis in patients with triple-negative breast cancer. Oncol Lett 9: 149-152.

15. Criscitiello C, Disalvatore D, De Laurentiis M, Gelao L, Fumagalli L, et al. (2014) High Ki-67 score is indicative of a greater benefit from adjuvant chemotherapy when added to endocrine therapy in luminal B HER2 negative and node-positive breast cancer. Breast 23: 69-75

16. Shevra CR, Ghosh A, Kumar M (2015) Cyclin D1 and Ki-67 expression in normal, hyperplastic and neoplastic endometrium. J Postgrad Med 61: 1520

17. Choi YS, Lee KE (2015) The significance of miR-34a expression in endometrial carcinogenesis: correlation with expression of p16 and ki-67 proteins in endometrial cancers. J Cancer Prev 20: 268-274.

18. Yu CG, Jiang XY, Li B, Gan L, Huang JF (2015) Expression of ER, PR, C-erbB-2 and $\mathrm{Ki}-67$ in endometrial carcinoma and their relationships with the clinicopathological features. Asian Pac J Cancer Prev 16: 6789-6794.

19. Horree N, Van Diest PJ, Sie-Go DM, Heintz AP (2007) The invasive front in endometrial carcinoma: higher proliferation and associated derailment of cell cycle regulators. Hum Pathol 38: 1232-1238.

20. Apostolou G, Apostolou N, Biteli M, Kavantzas N, Patsouris E, et al. (2014) Utility of Ki-67, p53, Bcl-2, and Cox-2 biomarkers for low-grade endometrial cancer and disordered proliferative/benign hyperplastic endometrium by imprint cytology. Diagn Cytopathol 42: 134-142.

21. Ozuysal S, Oztürk H, Bilgin T, Filiz G (2005) Expression of cyclin D1 in normal, hyperplastic and neoplastic endometrium and its correlation with Ki-67 and clinicopathological variables. Arch Gynecol Obstet 271: 123-126.

22. Feng W, Malpica A, Skaland I, Gudlaugsson E, Robboy SJ, et al. (2013) Can proliferation biomarkers reliably predict recurrence in World Health Organization 2003 defined endometrial stromal sarcoma, low grade? PLoS One 8: e75899.

23. Johannessen AL, Torp SH (2006) The clinical value of Ki-67/MIB-1 labeling index in human astrocytomas. Pathol Oncol Res 12: 143-147.

24. Chiloiro S, Bianchi A, Doglietto F, de Waure C, Giampietro A, et al. (2014) Radically resected pituitary adenomas: prognostic role of $\mathrm{Ki} 67$ labeling index in a monocentric retrospective series and literature review. Pituitary 17: $267-276$

25. Apostolou G, Apostolou N, Biteli M, Kavantzas N, Patsouris E, et al. (2014) Utility of Ki-67, p53, Bcl-2, and Cox-2 biomarkers for low-grade endometrial cancer and disordered proliferative/benign hyperplastic endometrium by imprint cytology. Diagn Cytopathol 42: 134-142.

26. Mourtzikou A, Kosmas K, Marouga A, Stamouli M, Pouliakis A, et al. (2012) The use of an immunocytochemical double-labeling staining can display the distribution of $\mathrm{BCl}-2 / \mathrm{Ki}-67$ cells in endometrial adenocarcinomas as well as in normal endometrium. Clin Lab 58: 133-144. 